\title{
Token Economy for Sustainable Education in the Future: A Scoping Review
}

\author{
Kim Hua Tan ${ }^{1, *(\mathbb{D}}$, Mathura Kasiveloo ${ }^{1}$ and Imran Ho Abdullah ${ }^{2} \mathbb{0}$ \\ 1 Faculty of Education, Universiti Kebangsaan Malaysia, Bangi 43600, Malaysia; mathura1711@gmail.com \\ 2 Faculty of Social Sciences \& Humanities, Universiti Kebangsaan Malaysia, Bangi 43600, Malaysia; \\ imranho@ukm.edu.my \\ * Correspondence: kimmy@ukm.edu.my; Tel.: +60-192-735-440
}

Citation: Tan, K.H.; Kasiveloo, M.; Abdullah, I.H. Token Economy for Sustainable Education in the Future: A Scoping Review. Sustainability 2022, 14, 716. https://doi.org/10.3390/ su14020716

Academic Editor: Jordi Colomer Feliu

Received: 10 November 2021

Accepted: 4 December 2021

Published: 10 January 2022

Publisher's Note: MDPI stays neutral with regard to jurisdictional claims in published maps and institutional affiliations.

Copyright: (c) 2021 by the authors. Licensee MDPI, Basel, Switzerland. This article is an open access article distributed under the terms and conditions of the Creative Commons Attribution (CC BY) license (https:// creativecommons.org/licenses/by/ $4.0 /)$.

\begin{abstract}
This research aims to examine the use of a token economy for education sustainability. It presents a recent review and evaluation of the token economy used among young learners and learners with special needs for behavior management and learning engagement in teaching. Online articles from Google Scholar, ERIC, and UKMLibrary were used. The terms used for reviewing the articles were token economy, token systems, positive reinforcement, and rewards. The scoping review protocol was used for this study. A total of 60 relevant articles published from 2000 to 2020 were filtered and grouped into three major themes for review: behavior management, learning engagement, and types of tokens. Findings suggested that although previous research had examined the impact of a token economy on behavior management and learning engagement, there was limited research on the correlation between teaching methods and social fairness. Teachers as the main participants in assessing the effectiveness of a token economy, were also lacking. Additionally, the use of social and physical reinforcers was found to assist in obtaining the desired behaviors and learning engagement from participants, thereby enabling them to sustain learners' interest in future lessons.
\end{abstract}

Keywords: token economy; token systems; positive reinforcement; rewards; young learners

\section{Introduction}

A token economy is frequently used to monitor pupil behavior, particularly among young learners and pupils with special needs. A token economy is thought to aid educators in controlling pupils' disruptive behavior and is frequently utilized to attract students' attention. When participants meet the desired behavior, they are given tokens as a form of positive reinforcement. Among the numerous types of token economy are tangible incentives, intangible benefits, positive reinforcements, and negative reinforcements. Despite its widespread use, only minimal research has been conducted on learner engagement in the use of a token economy. This scoping review provides a systematic investigation of the use of a token economy for behavior management and learner engagement in diverse classroom contexts. The implementation of a token economy in different classroom settings provides equal opportunities for learners to develop themselves. Likewise, sustainable education is related to providing equal opportunities for young learners to gain education. The use of a token economy is seen to be a vital tool to motivate learners to come to education institutions to gain knowledge. Motivating learners to want to continue learning is crucial for sustaining interest in education.

The token economy is based on Skinner, B.F. [1]'s operant learning theory, which suggests that rewards and punishments influence behavior. Positive and negative reinforcements are used in Skinner's theory to encourage good and desired behaviors, while discouraging undesirable and unwanted ones. Skinner [1] indicated that every action has a consequence; if the outcome is positive, then a person benefits. In this case, this person will be rewarded. However, if the outcome is less than ideal, then the individual is more likely to be demotivated and avoid repeating the process in the future. Through this 
process, we develop our behaviors and come to learn what is proper and useful and what is not. When teachers commend students for their good behavior, students will eventually emulate such behavior again in the future. When students are not rewarded for their actions, they will begin to act in ways that can be rewarded. In this case, teachers should not allow students to wait for prizes for an extended period because they will become frustrated if they are not rewarded as promised. This situation may cause children to resist achieving the teachers' expectations because they feel deceived or exploited.

Rewards are another component of the token economy system. Participants will be regularly rewarded only when they exhibit the required behavior. This situation will encourage participants to continue exhibiting the desired behavior that will qualify them for the prizes [1]. The term "rewards" is also used in Skinner's operant condition theory [1], which states that rewards are utilized to increase participants' desired response. When individuals are rewarded for their actions, they will continue to act in the same way to receive additional incentives employed to boost or intensify the teacher's intended response.

Another form of token economy is positive reinforcement. For example, a token economy can entail giving praise immediately after children put away their toys. Praise can also be offered by acknowledging the desired behavior and rewarding children for doing so. This strategy will encourage young people to repeat the same activities in the future. Anything that promotes or improves the desired behavior, such as specific material prizes, events, or situations, is considered positive reinforcement. Praise, getting out of unpleasant work, token rewards, candy, additional downtime, and pleasurable activities are examples of positive reinforcement in classrooms. In Western classrooms, this type of token economy is extensively used.

Sustainable education pedagogies encourage students to ask questions, analyze, think critically, and make decisions. These pedagogies shift from teacher-centered to studentcentered lessons, as well as from rote memorization to active learning. These pedagogies are frequently centered on problems or issues. Critical thinking, social critique, and studies of local contexts are encouraged by these pedagogies. They strive for constructive change and assist students in developing a sense of social justice and community self-efficacy.

UNESCO recognized 10 fundamental components of quality education related to individual learners and educational systems. Five of these factors are at the level of learners. First, learners should be located. Second, learners' expertise and experiences should be acknowledged. Third, content must be made relevant. Fourth, numerous teachings and learning processes should be used. Lastly, the learning environment must be improved. These elements of quality education are crucial for sustainable education for the future, which is evidenced by the implementation of a token economy in the classroom. By using a token economy, pupils are recognized for their effort during teaching and learning sessions. Moreover, they are given the opportunity for self-improvement by creating a competitive learning environment.

Sustainable education ensures that all students receive a high-quality education that is inclusive and equitable, and that lifelong learning opportunities are available to all. Quality education and opportunities for lifelong learning are critical to ensuring a full and productive life for all people in achieving sustainable development. The period of early childhood is crucial for a child's cognitive development. Primary education has been found to improve a child's social, emotional, and intellectual development, as well as their readiness for further learning. The implementation of a token economy at this stage is seen as crucial to develop the learner's cognitive and social skills.

With reference to the United Nations' (UN) Sustainable Development Goals, there are a few points that can be linked to the implementation of a token economy in our education institutions. Out of their 17 goals, three goals can be linked to the token economy system, which are providing quality education, enforcing gender equality, and reducing inequality. The token economy is a form of positive reinforcement. It does not penalize learners for their mistakes. It motivates them to perform better. The implementation of a token economy is able to motivate learners from different backgrounds to learn. A token 
economy provides the opportunity for all to be rewarded for their positive actions. Equal opportunities are given to the learners to perform and be rewarded by their teachers. A quality education is assessed by the outcome of the learners. Motivating the learners to gain knowledge using a token economy is seen as crucial for the learners' behavior management and learning engagement towards achieving quality education.

Skinner [1] explained that any reinforcing stimulus that strengthens the targeted behavior is called a positive reinforcer. Therefore, a token economy is a positive method to obtain desired behaviors from participants in a safe manner, without negatively affecting them physically or emotionally. The intervention using a token economy that this study selected is a method from Skinner's operant conditioning theory (Figure 1). In this theory, the response mentioned is when participants can show the desired behavior needed by the researcher. They should be able to feel motivated and intrinsically triggered to show the desired behavior expected by the researcher.

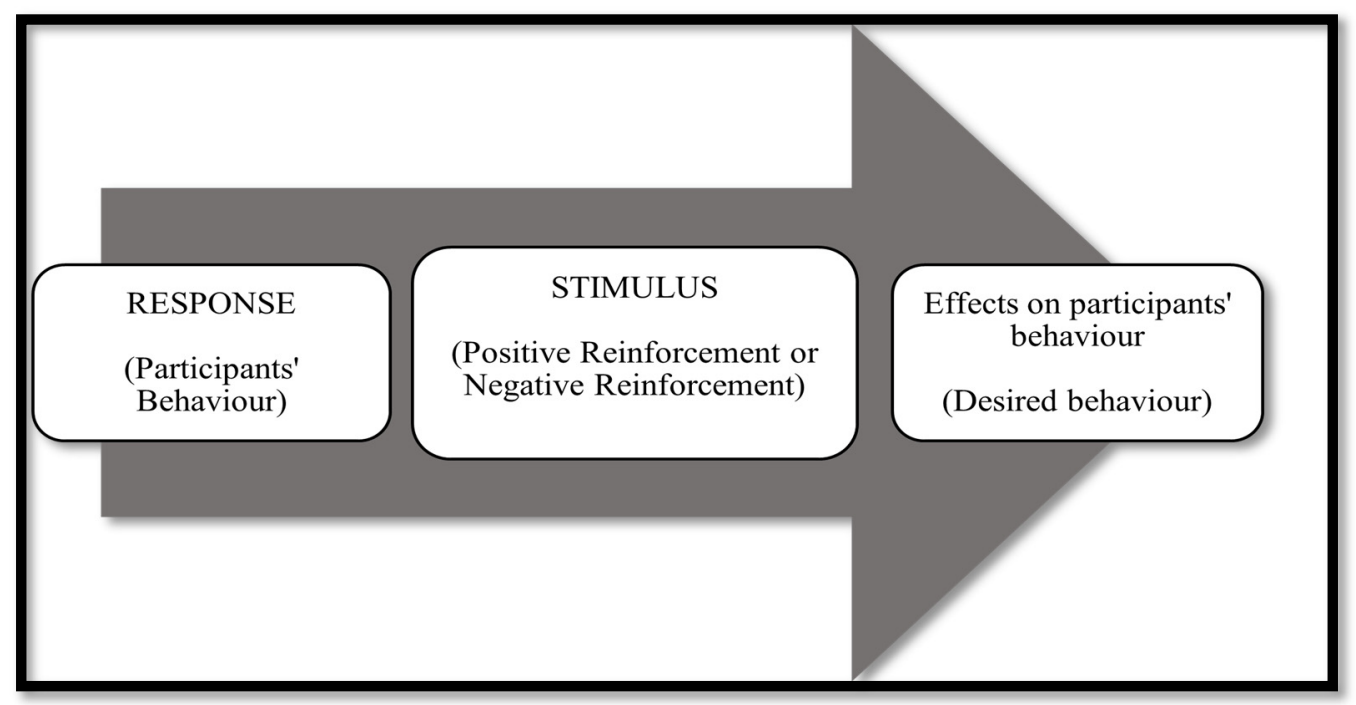

Figure 1. Skinner's operant conditioning theory.

Reinforcement is defined as a "process of enhancing the rate or probability of a behavior in the form of a response by delivery either immediately or shortly after completing the activity" [1] in operant conditioning and behavior analysis. The reinforcement theory of motivation emphasizes a person's emotional and psychological state of mind. Reinforcement theory focuses on changes that occur in each person as a result of performing certain acts or engaging in certain behaviors. Consequently, Skinner explained that "the external environment must be structured properly and positively to drive the participants towards the desired behavior." The theory of reinforcement motivation is a significant tool for controlling people's activities and behaviors. This view disregards the reasons behind people's actions.

In theory, the two main types of reinforcements are positive and negative reinforcements (Table 1). A token economy is classified as positive reinforcement because it gives incentives to participants rather than giving punishments. Incentives motivate the participants to continue portraying the same behavior in order to be rewarded frequently. Numerous types of positive reinforcement are commonly used in various settings. As seen in this review, numerous research papers have discussed many of these reinforcement techniques under the title of "token economy". 
Table 1. Positive and negative reinforcements.

\begin{tabular}{ll}
\hline & Operant Behavior \\
\hline $\begin{array}{l}\text { Positive reinforcement } \\
\text { - Praise }\end{array}$ & \\
- Monetary rewards & Negative reinforcement \\
- Natural reinforcers & - Taking away \\
- Social reinforcers & $\bullet$ Removing \\
- Tangible reinforcers & \\
\hline
\end{tabular}

A token economy often comes together with more than one stimulus. This system uses a few types of positive reinforcement to achieve desired behaviors. Commonly, researchers use tokens and tangible reinforcers as stimuli for their study. Other flexible strategies also use token economy systems based on the setting and on specific targeted participants.

Researchers can follow the steps to achieve effective outcomes with the use of the token economy system (Figure 2). Accordingly, researchers should follow these steps to ensure the effectiveness of the implementation of a token economy.

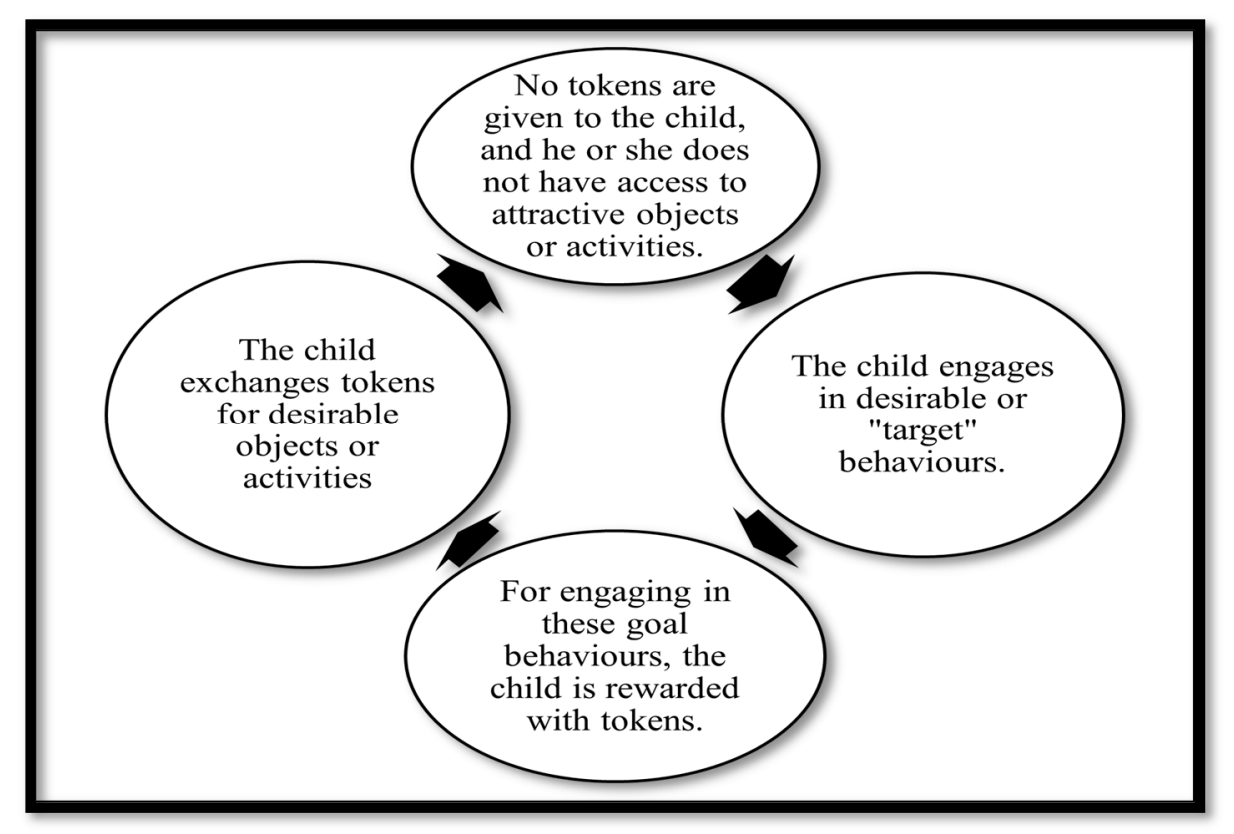

Figure 2. Basic token economy cycle (Miltenberger, 2008).

The first step is to decide on the desired behavior that researchers intend to achieve at the end of the research. The second step is introducing the targeted behavior to participants. This step aims to ensure that they are aware of the behaviors they must portray to achieve the tokens. The third step is the implementation of the intervention. The intervention in a token economy should be consistent with the participants' needs. In other words, rewards or tokens should attract the participants' interest. If this method fails, then the intervention will be a failure because it will be unable to boost participants' motivation to engage in the targeted behaviors. Therefore, the various elements of a token economy should be considered to obtain effective outcomes.

\section{Materials and Methods}

A scoping review is a relatively new approach to evidence production and differs from systematic reviews in purpose and aims. Grant and Booth [2] defined scoping reviews as "an initial evaluation of potential scale and scope of available research literature". This approach seeks to determine the nature and extent of research evidence (i.e., often including 
ongoing research). Arksey and $\mathrm{O}^{\prime}$ Malley [3] explained that scoping reviews are crucial for four reasons: (1) to determine the scope, range, and type of existing research on a given topic or question; (2) to assess the benefit of conducting a comprehensive examination; (3) to synthesize and disseminate research findings over a large body of evidence; and (4) to identify research gaps in the literature to facilitate future research planning and procurement. Scoping reviews are used to organize and chart the available literature on a topic. An overview of these scoping review steps are simplified in Figure 3 below.

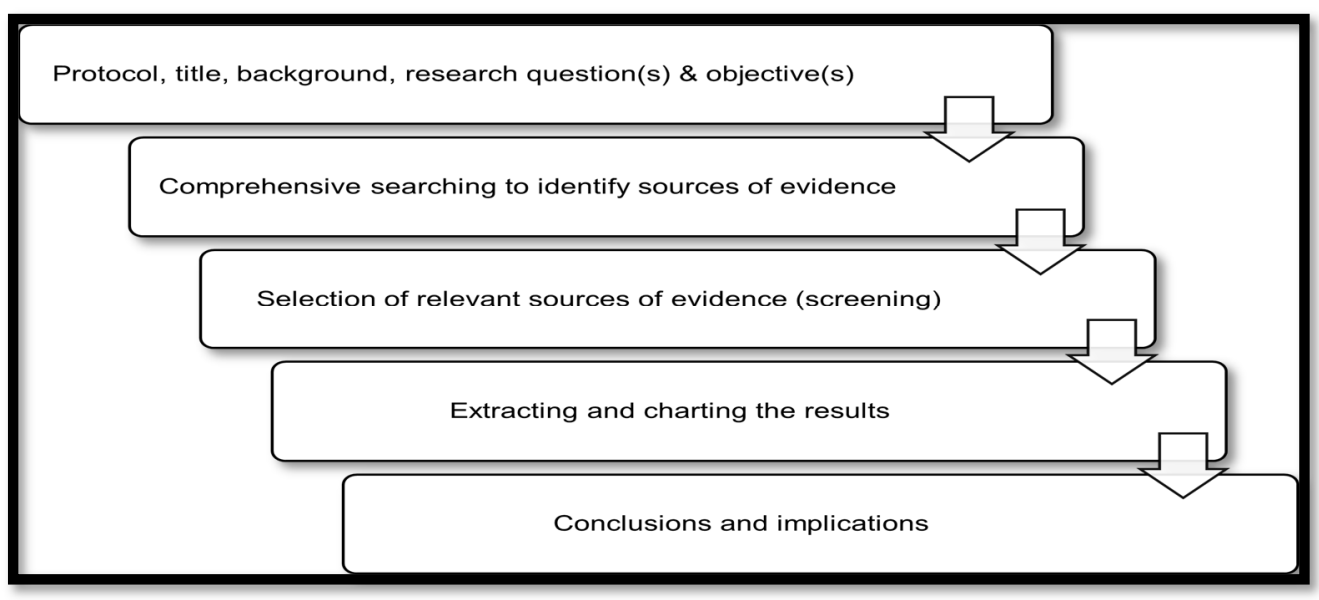

Figure 3. Overview of scoping review steps [4].

A total of 60 journal articles were chosen to examine the various instruments, approaches, and tactics for implementing a token economy among learners. These articles were published in various settings between 2000 and 2021. The articles chosen were related to education settings only. The Prisma flow diagram is shown in Figure 4. A total of 102 articles were found from the database, with a combination of journal articles, research papers, and duplicate citations. Relevant articles were systematically chosen to conduct this scoping review.

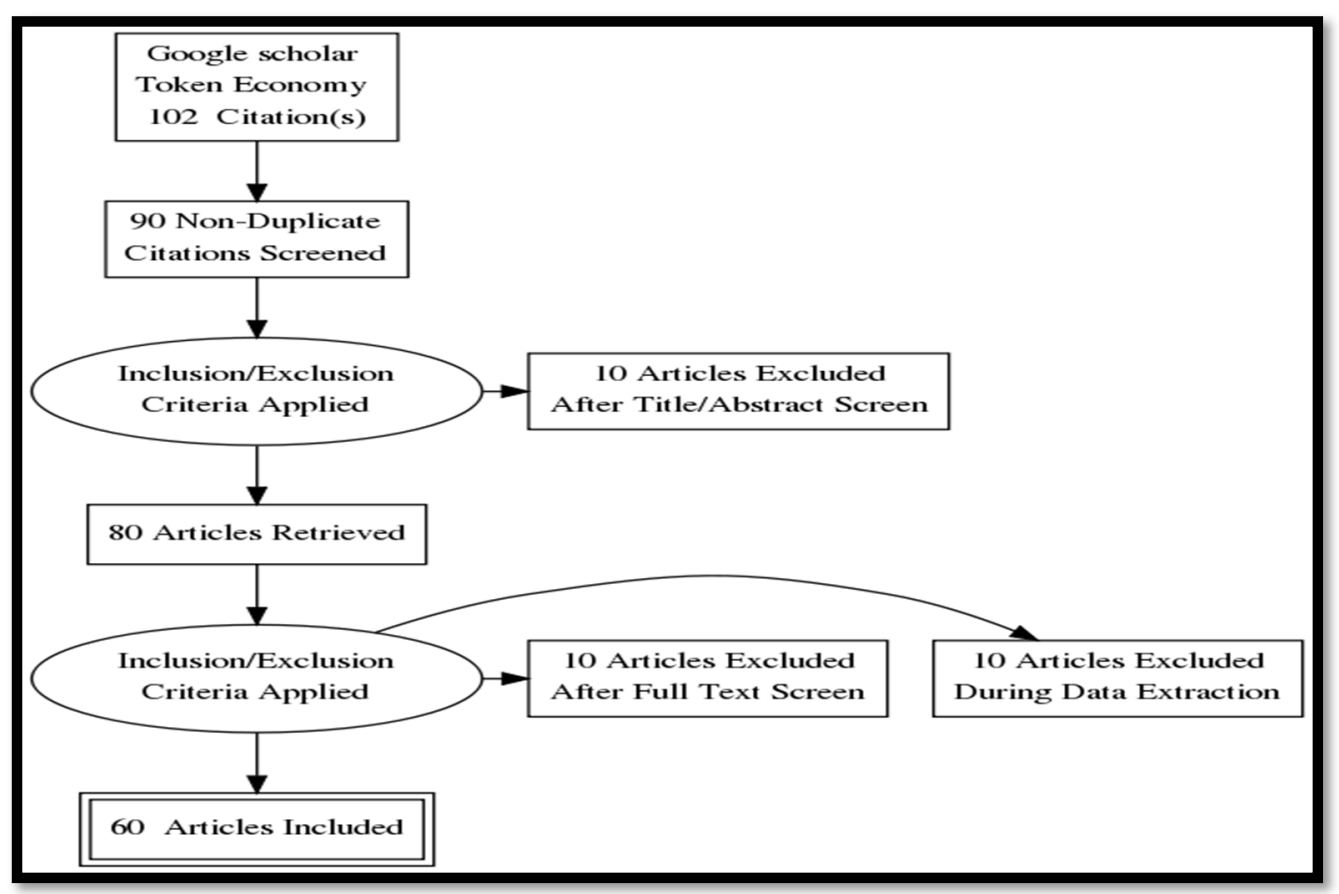

Figure 4. Prisma flow diagram. 
Table 2 shows the inclusion and exclusion criteria for the articles chosen. In general, a few inclusion criteria were applied when choosing the articles. First, the articles had to be published in 2000-2021. Second, the articles had to focus on education settings. Third, articles had to be based on positive reinforcement interventions (token economy) applied to the participants. Lastly, the findings of the articles had to be able to explain the outcomes of implementing a token economy among learners.

Table 2. Inclusion and exclusion criteria.

\begin{tabular}{ccc}
\hline Criteria & Inclusion Criteria & Exclusion Criteria \\
\hline Focus of study & Token economy in education & Token economy in different settings \\
\hline Participants & Learners/students/pupils & Non learners/students/pupils \\
\hline Types of intervention & Positive reinforcement & Negative reinforcement \\
\hline Context of study & Types of token economy/intervention procedure & No information on types of token economy used \\
\hline Types of outcomes & Behavior management and learning engagement & No information on behavior management and learning engagement \\
\hline
\end{tabular}

Excluded articles were mainly those that did not meet the timeframe. Articles that did not focus on participants from education settings were excluded. The articles chosen had to be linked to education settings. This was the main exclusion criterion. Some of the articles were found have employees as their participants, rather than those from the education setting. Some excluded articles did not follow the format of a well-designed study, while a few lacked vital information.

From the 80 articles retrieved, 60 were chosen for the scoping review after full-text screening and data screening.

- Scoping review research questions

Research questions constitute an attempt to articulate our curiosity. Curiosity should not lead to questions being asked in a random manner [5] but in relation to what is currently known about the topic of concern.

The guiding questions for this research were as follows: What is the relationship of using a token economy for behavior management and learning engagement in young learners? How could the use of a token economy help in achieving education sustainability and its goals? This review was conducted to evaluate the method of token economy used to engage young learners in learning and the possible outcomes of the research.

\section{Results}

Research trends based on the articles collected were categorized according to their year (Figure 5). The highest number of articles (34) on the token economy was collected from 2015 to 2020, which covered over half of the total articles analyzed. This result shows that the token economy is a current trend among education researchers.

The different regions of the articles collected were divided into three categories: Asian, European, and other countries. The analysis indicated that 31 articles described research conducted in Asian countries, which mainly included Indonesia, Thailand, India, Malaysia, and Vietnam. Only four articles were acquired from Malaysia. Meanwhile, there were 25 articles from non-Asian countries, such as Canada, the UK, and the US. A total of four articles were from other countries, such as Tehran and Saudi Arabia. These articles showed that the implementation of the token economy is popular in Asian and European countries.

Different settings were identified on the basis of the articles analyzed. The settings of the implementation of the token economy were categorized. Eight articles were based on research conducted in a kindergarten setting, 30 articles on a primary school setting, 13 articles on a secondary school setting, and 9 articles on a university setting. These numbers show that the majority of the articles were based on research conducted in primary schools. Therefore, the token economy system is considered applicable and practical for implementation in a primary school setting. The highest number of research studies involved 
young learners. The implementation of a token economy in young learners appears to be highly effective based on the data obtained from the journal articles.

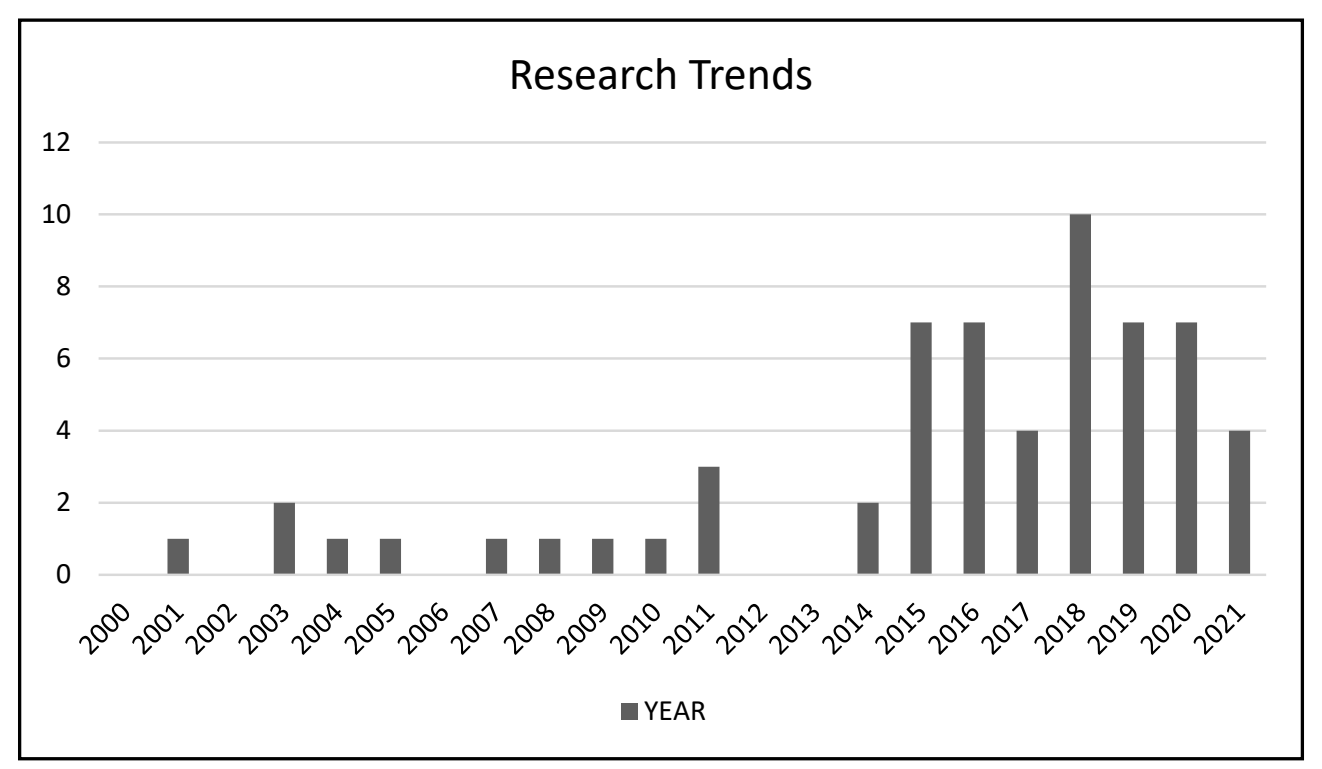

Figure 5. Research trends.

The types of research participants were divided into two categories, namely normal participants and participants with special needs (e.g., autism, ADHD, and learning disabilities). A total of 44 articles focused on participants with normal abilities and 16 articles on participants with special needs. The token economy is an intervention to be implemented as a treatment and can also be used to solve problems in teaching and learning.

The implementation of a token economy was categorized according to two main elements: behavior management and learning engagement. The majority of the studies conducted were focused on learning engagement, with 30 articles. Behavior management followed, with 23 articles, and the remaining seven articles focused on behavior management and learning engagement. These numbers show that the token economy system of Skinner for behavior modification is currently used to gain attention from participants during teaching and learning sessions, apart from motivating them to learn.

Numerous types of tokens were used in the articles analyzed. These tokens were divided into two categories: positive and negative reinforcements. Tables 3 and 4 list the examples of tokens from the articles.

On the other hand, the idea of the token economy found in past research significantly contributes to education sustainability. The result of each study is closely linked to the goals of sustainable education listed by the United Nations (UN). The concern of providing quality education equally to all young learners is met through the implementation of a token economy in the classroom. Table 5 summarizes the studies that were chosen for this scoping review. 
Table 3. Examples of positive reinforcement tokens.

\begin{tabular}{|c|c|}
\hline \multicolumn{2}{|c|}{ Positive Reinforcement } \\
\hline $\begin{array}{l}\text { Physical reinforcers } \\
\text { - Cookies } \\
\text { - } \text { Books } \\
\text { - Stickers } \\
\text { - Candy } \\
\text { - Gifts } \\
\text { - Crayons } \\
\text { - Pencils } \\
\text { - Chocolates } \\
\text { - Plaques } \\
\text { - Fruits } \\
\text { - Certificates } \\
\text { - Counterfeit money }\end{array}$ & $\begin{array}{l}\text { Activity reinforcers } \\
\text { - } \text { Choose a game } \\
\text { - } \text { Recess/break } \\
\text { - Extra time } \\
\text { - } \text { Watch TV } \\
\text { - } \text { Play } \\
\text { - Snack with the teacher } \\
\text { - No homework for a week }\end{array}$ \\
\hline \multirow[t]{2}{*}{$\begin{array}{l}\text { Social reinforcers } \\
\text { - Grades } \\
\text { - Applause } \\
\text { - Smiles } \\
\text { - Stickers } \\
\text { - Awards } \\
\text { - Compliments } \\
\text { - Nomination in the school bulletin } \\
\text { - Hand stamp } \\
\text { - Display work }\end{array}$} & $\begin{array}{l}\text { Rental privileges } \\
\text { - Games } \\
\text { - Hand puppets } \\
\text { - Laptop } \\
\text { - Table toys } \\
\text { - Sports } \\
\text { - Books } \\
\text { - CDs } \\
\text { - Magazines } \\
\text { - Colouring books } \\
\text { - Jump rope }\end{array}$ \\
\hline & $\begin{array}{l}\text { - } \text { Classroom privileges } \\
\text { - Constructing rules } \\
\text { - Collecting books } \\
\text { - Being a tutor } \\
\text { - Being the monitor } \\
\text { - } \text { Be first in line }\end{array}$ \\
\hline
\end{tabular}

Table 4. Examples of negative reinforcement tokens.

\begin{tabular}{|c|c|}
\hline \multicolumn{2}{|c|}{ Negative Reinforcement } \\
\hline $\begin{array}{l}\text { Warning } \\
\text { Memorizing vocabulary } \\
\text { Decreasing students' points } \\
\text { Moving students' seats }\end{array}$ & $\begin{array}{l}\text { Inconvenient punishment } \\
\text { Timeouts/timeout chairs } \\
\text { Deprivation of their favorite activities/items } \\
\text { Running around the field } \\
\text { Standing in the area } \\
\text { Doing assignments outside the classroom } \\
\text { Standing in front of the class } \\
\text { Throwing away the rubbish }\end{array}$ \\
\hline $\begin{array}{l}\text { Spoken punishment } \\
\text { Use nonverbal cues } \\
\text { Use a penalty } \\
\text { Assign detention or timeout } \\
\text { Design an individual contract } \\
\text { Punishment by words } \\
\text { Punishment by action }\end{array}$ & $\begin{array}{l}\text { Physical punishment } \\
\text { Pinching }\end{array}$ \\
\hline
\end{tabular}


Table 5. Selected articles of young learners and special needs learners.

\begin{tabular}{|c|c|c|c|}
\hline Study & Objective & Intervention & Results \\
\hline [6] & $\begin{array}{l}\text { The purpose of this study was to compare the } \\
\text { effectiveness of two kinds of reinforcements, tangible } \\
\text { reinforcements and social reinforcements, on the } \\
\text { academic achievement of eighth-grade female students } \\
\text { with intellectual disabilities in the science subject. }\end{array}$ & $\begin{array}{l}\text { Physical reinforcer and } \\
\text { social reinforcement }\end{array}$ & $\begin{array}{l}\text { - There was a significant difference in academic } \\
\text { achievement scores between the groups, and } \\
\text { there was a significant difference in academic } \\
\text { achievement scores between the groups before } \\
\text { and after the intervention. } \\
\text { The tangible reinforcement group had } \\
\text { a considerably greater mean difference in } \\
\text { accomplishment scores than the social } \\
\text { reinforcement and control groups. }\end{array}$ \\
\hline
\end{tabular}

[7] The research aimed to determine the effect of the application of the token economy method on mathematics learning motivation.
Token economy

- There is a considerable difference in motivation to learn mathematics between students who are taught using the token economy technique and students who are not taught using the token economy method.
This paper discusses a study on students' and teacher perceptions of the token economy system and the means of the implementation in Saudi schools.

Physical reinforcer
Implementation of a rewards system in the classroom has become a common method of encouraging and controlling student behavior, particularly among younger pupils.
The study aimed to define the effect of a token

[9] economy system in improving social, academic, and behavior skills with children.
Token economy

Using a token economy helps students to accomplish the targeted reactions. A positive learning environment is a recipe for increasing students' participation in academic activities. Furthermore, by extending the positive behaviors that children exhibit in the classroom to other areas, students can improve their social skills.
The purpose of this study was to employ and evaluat
[10] the use of a spelling racetrack with a single general education student with low performance in spelling.
Racetrack reward system

Significant differences were found for treatment for correct answers $(\mathrm{F}=32 ; \mathrm{df}=3 ; p=0.0004)$ and errors $(\mathrm{F}=26 ; \mathrm{df}=3 ; p=0.001)$. Follow-up tests using a Schefft's F test found significant differences for correct answers and for errors, except for the initial baseline and the last baseline
[11] This study aimed to increase students' concentration on learning and facilitate this process in the classroom.
Physical reinforcer
The use of token economies helps to improve students' attentiveness while completing assignments.

This study aimed to examine the effects of using positive reinforcement techniques to reduce disruptive

behavior among children on the Attention Deficit Kuala Lumpur

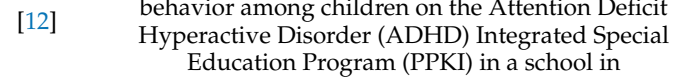 \\ [12] behavior among children on the Attention Deficiter
Hyperactive Disorder (ADHD) Integrated Spe
Education Program (PPKI) in a school in}

To evaluate the effectiveness of the token economy by recording the degree of participation in

[13] an introductory psychology class before, during, and after implementation of the token economy
Positive reinforcement and rewarding technique
There was a decrease in disruptive behavior and an improvement in pupils' attentiveness.

Level of directed and nondirected participation grew during the token economy and then returned to baseline after the token economy was removed.

Token economy

The paired-samples t-test suggested significant difference between the beginning and end of Phase B, t $(11)=15.34 ; p<0.001$. The mean score for Week 7 was 26.57 $(\mathrm{SD}=5.05)$ and the mean score for Week 12 was

The aim of this study was to analyze the relationsh between a token reward system and reading comprehension scores

Physical reinforcer
$15.58(\mathrm{SD}=5.299)$

- $\quad$ These data indicate that the participants' combined reading comprehension scores at the end of Phase B decreased significantly after the token reward system was discontinued after Week 6 . 
Table 5. Cont.

\begin{tabular}{|c|c|c|c|}
\hline Study & Objective & Intervention & Results \\
\hline [16] & $\begin{array}{l}\text { To study how behavior modification can be used to } \\
\text { enhance students' English handwriting. }\end{array}$ & $\begin{array}{l}\text { Token economy, Differential } \\
\text { Reinforcement of Low Rates (DRL) }\end{array}$ & $\begin{array}{l}\text { - The children's handwriting speed continued to } \\
\text { improve. The } 12 \text { students improved their } \\
\text { handwriting and writing speed. }\end{array}$ \\
\hline [17] & $\begin{array}{l}\text { The purpose of this study was to realize a predictive } \\
\text { model of rewards and identify reward predictors for } \\
\text { reading motivation. }\end{array}$ & Physical reinforcer, social reinforcer & $\begin{array}{l}\text { Reward process could explain the differences in } \\
\text { intrinsic, extrinsic, and global } \\
\text { reading motivation. }\end{array}$ \\
\hline [18] & $\begin{array}{l}\text { To evaluate the effectiveness of the use of cards in a } \\
\text { trading card game as education rewards. }\end{array}$ & $\begin{array}{l}\text { Web-based multiplayer trading card } \\
\text { game to allow teachers to choose } \\
\text { cards as rewards }\end{array}$ & $\begin{array}{l}\text { Using in-game cards as educational incentives } \\
\text { can assist students to enhance their academic } \\
\text { results, regardless of whether they are boys or } \\
\text { girls, high achievers or low achievers, and have } \\
\text { a high or low purpose of using the game and } \\
\text { in-game products as educational rewards. }\end{array}$ \\
\hline
\end{tabular}

The purpose of this study was to examine the effects of [19] a token economy, in the form of a lottery system, on noncompliant behavior for a group of 10 3rd grade students enrolled in a K-8th grade urban school.
Token economy

- The lottery system intervention was successful in reducing noncompliant conduct among students during the trial.

The results demonstrated a decrease in noncompliant behavior, as well as a student preference for the lottery, as measured by a post-intervention social validity survey.
To determine Kinesiology students' perceptions of

[20] a token economy in flipped Human Anatomy and Physiology I and II courses
Physical reinforcer

Providing students with rewards to reinforce specified student actions is effective to reinforce student engagement and improve the instructor's pedagogical approach.
The present study depicted the utility of including basic behavior-analytic principles and strategies to facilitate on-task behavior in a classroom for individuals with autism
Including basic behavior-analytic procedures in a student's timetable would reduce difficult behaviors while increasing socially important substitute behavior.
Evaluate the use of achievement badges in the

TRAKLA2 online learning environment, where

[22] students solve interactive, automatically assessed exercises in a Data Structures and Algorithms course throughout the semester
Achievement badges

Achievement badges had a statistically significant impact on various aspects of students' conduct, and students had generally positive sentiments toward them.

Students in the therapy group participated in more sessions and spent a longer time in the learning environment overall.
The present research was undertaken to determine the
[23] effectiveness of a token economy in reducing temper tantrums among children with intellectual disabilities.
Token economy

The F ratio both before and after interventions suggested that the token economy had a positive effect on temper tantrums among intellectually impaired children.
The purpose of this investigation was to determine if a token reinforcement program could decrease three

[24] inappropriate behaviors (getting out of seat, shouting out, and poor posture) in an elementary student with learning disabilities.
Token economy

The findings showed that giving tokens for the absence of the three goal behaviors was a successful technique.
The purpose of this study was to evaluate the effectiveness of a reading racetrack with direct instruction flashcards and a token system on sight word acquisition for two primary students with severe conduct disorders
The study centered on determining the effect of

[26] a token economy on the academic achievement of secondary school students.
Token economy
There were several beneficial consequences of introducing the token economy. While reading books, the participants began to generalize, and they expressed an interest in working with a variety of adults. 
Table 5. Cont.

\begin{tabular}{|c|c|c|c|}
\hline Study & Objective & Intervention & Results \\
\hline [27] & $\begin{array}{l}\text { This study aimed to investigate the effect of reward } \\
\text { and punishment on student achievement } \\
\text { and discipline }\end{array}$ & Physical reinforcer, social reinforcer & $\begin{array}{l}\text { - The effect of reward and punishment on } \\
\text { student accomplishment and discipline, among } \\
\text { other things, improves students' excitement for } \\
\text { learning, pushes students to sustain their } \\
\text { achievements, and makes students more } \\
\text { disciplined in their studies. }\end{array}$ \\
\hline
\end{tabular}

The purpose of this study was to determine the [28] effectiveness of a token economy in improving the attention of children with ADHD when completing a task.
Token economy

Using token economy to increase attention in children with ADHD is beneficial.

The child is motivated to demonstrate the intended behavior if the parent promises to deliver token economy as soon as the target behavior shows.
The purpose of this research was to find out the eighth [29] grade students' motivation in learning English after given rewards at the SMPN 3 Rambah.
57 students were rated as having a strong drive to study English after receiving rewards, while three students were assessed as having fair motivation.

Physical reinforcer

- The average student questionnaire score was 78.8 , indicating that their motivation was in the "good" category on average.
The purpose of the present case report was to evaluat the effects of an individual token economy with a young child with a severe behavioral disorder
Token system
Using a token system boosted the participant's rate of completion of box work.

Token program enhanced assignment completion and decreased the occurrence of inappropriate classroom behavior.

To examine the link between intrinsic motivation and external rewards by describing the experiences of

\section{twenty-seven academically underperforming
adolescents who were enrolled in an after-school
program in a New York City public junior high school \\ twenty-seven academically underperforming
adolescents who were enrolled in an after-school
program in a New York City public junior high school \\ twenty-seven academically underperforming
adolescents who were enrolled in an after-school
program in a New York City public junior high school that implemented a token economy.} that implemented a token economy.

Objectives of this study were to increase spontaneous [32] requests and decrease challenging behaviors among children with autism by introducing a secondary reinforcer during therapy based on the ABA model
Physical reinforcer, social reinforcer

Physical reinforcer
Token economy is an effective tool for motivating students who have underperformed to engage in and eventually gain information from their participation in school-based tasks.

Using a mixture of primary and secondary reinforcers during ABA therapy generated better results than using a single reinforcer during ABA therapy.

Reinforcers increase children with autism's motivation to learn, encourage them to answer questions asked by the teacher, and manage their problematic behaviors.

\section{This study aimed to apply a learning model including [33] development of a syllabus and a Learning Implementation Plan (RPP).}

Token economy

- $\quad$ Helped to boost motivation and student learning outcomes in terms of the process and learning outcomes.
The study explored whether this impairment can be remediated by increasing rewards for correct

[34] responding or by reinforcing correct conditional choice behavior with situationally specific outcomes (differential outcomes)
Physical reinforcer

Physical reinforcer

Higher rewards and DO interventions can mitigate deficiencies in delayed conditional discrimination learning in ADHD on a DMTS task.

\section{(n) \\ [35] \\ This study investigated students' perceptions of the use of rewards in the classroom for enhancing behaviors and self- development}

Physical reinforcer and social reinforcer
Receiving rewards increased students' positive emotions.

- $\quad$ The data also revealed that they were pleased with the use of prizes, which aided their self-development as they were employed as external goals by a teacher.

Positive reinforcement for learning behavior was achieved using rewards.
This study will also focus on the benefits of potential rewards in motivating EYL students in learning English.
Physical reinforcer, activity reinforcer, social reinforcer
Students improved in their performance. Students were motivated to attain their learning objectives.

Children successfully accomplished their work. 
Table 5. Cont.

\begin{tabular}{|c|c|c|c|}
\hline Study & Objective & Intervention & Results \\
\hline [37] & $\begin{array}{l}\text { The purpose of this study was to analyze the types of } \\
\text { reward and punishment, as well as looking at the } \\
\text { possible reasons that they are used by teachers. }\end{array}$ & $\begin{array}{l}\text { Physical reinforcer, activity reinforcer, } \\
\text { social reinforcer }\end{array}$ & $\begin{array}{l}\text { - Generally used any form of praise }(49 \%) \text { in } \\
\text { offering social reinforcer, and teachers largely } \\
\text { used any type of nonverbal cue }(54 \%) \text { in } \\
\text { offering spoken punishments. } \\
\text { Social reinforcements are used for two reasons: } \\
\text { to raise students' excitement for learning } \\
\text { English and to motivate them during the } \\
\text { learning process. }\end{array}$ \\
\hline
\end{tabular}

- $\quad$ There were substantial differences in

To determine the effect of economic token therapy for reducing attachment behavior among kindergarten students.
Token economy attachment behavior in the intervention group compared to the control group before and after entering the token economy intervention $(p=0.000)$.

Token economy therapy has a good effect on reducing attachment behavior in kindergarten students at the start of the learning process. a variety of people, activities, surroundings, and goals.

Students' worry about the school setting and its surroundings can be reduced by an effective token economy, which can improve or preserve the conduct of students who support the learning environment.

This purpose of this study was to investigate the effects of implementing a web-based token economy,

[40] ClassDojo, on the academic behavior and performance of undergraduate sales students at a large AACSB-accredited university
Token economy

After using the token economy approach, students had considerably greater levels of the specified academic target behaviors, as well as higher self-reported effort, interest, and enjoyment in learning.
This research sought to examine and determine the impact that the token economy system as a behavior

[41] modifier has on disruptive behavior in classrooms among a group of primary level students in the parish of Manchester, Jamaica.
The use of tokens in reducing disruptive behavior was quite effective.

Token economy
There were fewer warnings and more time spent training students on how to participate in important class activities.
This study was intended to examine the effectiveness of behavioral counselling with a token economy and behavior contract techniques to reduce academic procrastination in students of SMP IT Insan Cendekia Semarang.
Token economy and behavior contract techniques
The differences in token economy and behavior contract techniques in reducing academic procrastination in the experimental group were $(\mathrm{M}=150.29, \mathrm{SD}=11.70)$ by the behavior contract, and $(\mathrm{M}=100.30, \mathrm{SD}=48.91)$ by the token economy.
The purpose of this study was to investigate whether third-grade literacy students who receive incentive

[43] rewards as part of their instruction would exhibit rewards as part of their instruction would exhibit
significantly higher reading habits and attitudes toward recreational reading than they did before the incentives were introduced.
Physical reinforcer

A repeated-measures MANOVA evaluating three variables before and after receiving incentives produced statistically significant results $(\mathrm{F}(2,17)=19.25, p=0.001$, partial Eta squared was.68, and power was 1.0). There was no difference in the overall number of books read in each four-week period $(\mathrm{t}(18)=0.08, p=0.93)$, or in the test scores averaged throughout each four-week period $(\mathrm{t}(18)=0.04, p=0.97)$, according to follow-up paired $t$-tests.

The reading attitude inventory's overall scores declined from $31(\mathrm{SD}=5)$ to $18(\mathrm{SD}=5)$ $(\mathrm{t}(18)=6.13, p=0.001)$. This decrease was statistically significant.
The purpose of the study was to determine the [44] relationship between teacher and students in terms of performance of primary school students in the Allahabad district.
Physical reinforcer
There was a substantial association between reinforcement and academic achievement among pupils in Allahabad district primary schools. According to the findings, schools should strengthen long-term reinforcement initiatives. 
Table 5. Cont.

\begin{tabular}{|c|c|c|c|}
\hline Study & Objective & Intervention & Results \\
\hline [45] & $\begin{array}{l}\text { This research is based on how the teacher builds } \\
\text { learning motivation in 5-6-year-old children }\end{array}$ & Social reinforcer & $\begin{array}{l}\text { Encourages pupils to keep up their } \\
\text { good behavior. }\end{array}$ \\
\hline [46] & $\begin{array}{l}\text { The purpose of this research was to determine the } \\
\text { effects of verbal rewards and punishments on gross } \\
\text { motor learning for children } 4-5 \text { years old. }\end{array}$ & Social reinforcer and punishment & $\begin{array}{l}\text { Proposed a method for teachers to use to help } \\
\text { children to improve their gross motor skills } \\
\text { using rewards and punishment. }\end{array}$ \\
\hline [47] & $\begin{array}{l}\text { The efficacy of three behavior management techniques } \\
\text { used in a Head Start classroom was examined. The } \\
\text { three techniques included: (a) techniques currently } \\
\text { used by the teacher, (b) response cost, and (c) the level } \\
\text { system (token economy). }\end{array}$ & Reinforcement and token economy & $\begin{array}{l}\text { Teacher's utilization of more positive } \\
\text { interactions with the students reinforced } \\
\text { appropriate behavior among the students. } \\
\text { Inappropriate behavior decreased. }\end{array}$ \\
\hline [48] & $\begin{array}{l}\text { This study examined the effectiveness of a token } \\
\text { economy combined with a mystery motivator in } \\
\text { decreasing inappropriate behaviors displayed by } \\
\text { a student with an autism spectrum disorder in a small } \\
\text { group setting. }\end{array}$ & $\begin{array}{l}\text { Mystery rewards, } \\
\text { points chart }\end{array}$ & $\begin{array}{l}\text { Token reinforcement on a variable interval } \\
\text { schedule combined with a mystery motivator } \\
\text { chosen from preference assessments can be } \\
\text { useful in reducing inappropriate or disruptive } \\
\text { behavior demonstrated by a student } \\
\text { with autism. }\end{array}$ \\
\hline [49] & $\begin{array}{l}\text { This study aimed to determine the effectiveness of } \\
\text { using a token economy in reducing the negative } \\
\text { behavior of autistic students. }\end{array}$ & Economy token and rewards & $\begin{array}{l}\text { The study's findings revealed a shift in } \\
\text { unfavorable behavior when economic tokens } \\
\text { were used. }\end{array}$ \\
\hline$[50]$ & $\begin{array}{l}\text { The current study examined the effectiveness of } \\
\text { a combined token economy and self-monitoring } \\
\text { package with youths displaying a major mental illness } \\
\text { and severe aggressive and persistent } \\
\text { disruptive behaviors. }\end{array}$ & Token economy and self-monitoring & $\begin{array}{l}\text { The children were exposed to either a token } \\
\text { economy or a combination of token economy } \\
\text { and self-monitoring, and their targeted } \\
\text { disruptive behaviors decreased dramatically. }\end{array}$ \\
\hline
\end{tabular}

\section{Discussion}

\section{- Behavior management}

The reviews indicated some important observations on the use of a token economy among young learners. Prawiro and Anggrarini [36] explained that students offered a wider range of rewards are more likely to be enthusiastic. They showed that teachers frequently use physical rewards in the form of stickers to recognize pupils' efforts. Pupils appear to be motivated when they are provided with stickers because they are rewarded with physical reinforcements that offer them the courage to compete for stickers. Their findings indicated that teachers used potential rewards in the classroom to create a positive learning environment for students, allowing them to enjoy the learning process [15,35,51,52].

Numerous studies have also been successfully conducted on behavior management using a token economy among young learners. The results shared by these studies have mostly supported the use of a token economy in young learners with disruptive behaviors or with any specific disabilities. The use of a token economy facilitated an increase in the number of assignments completed and a decrease in the number of disruptive classroom actions. Moreover, a shift in behavior is common during the intervention phase, indicating that positive reinforcement approaches can minimize students' disruptive conduct while also increasing their academic engagement. Furthermore, an intervention is judged beneficial because it assists instructors in effectively delivering courses and controlling the classroom. By following economic the token therapy, there were also substantial differences in attachment behavior between the intervention and control groups [11,30,38,49,50].

Classroom participation is considered a critical element in acquiring some knowledge. A token economy has also been used to direct the attention of learners to participate actively during teaching and learning sessions. In the use of a token economy, pupils appeared to be markedly willing to contribute to the lesson. Directed and nondirected involvement returned to baseline levels once instructors eliminated the token economy. Pupils' innate incentive to participate was not affected by the token economy. The relationship between the token economy's presence and the number and rate of involvement strongly suggested 
that tokens were the driving force behind increased engagement. Participants generally expressed their appreciation for the approach, stating that it made the class significantly engaging and engaged $[13,31,40,53]$.

The token economy is also considered to play a major role in the medical field. Hemamalini [23] indicated that the use of a token economy can help to reduce temper tantrums among intellectually disabled children. The aforementioned research proved that the token economy had a favorable impact on temper tantrums among intellectually impaired youngsters [41]. A token economy is a better technique to address troublesome conduct among intellectually impaired children, such as temper tantrums, than utilizing harsh measures. It also strengthens the desired behaviors expected from learners.

\section{- Learning engagement}

Regarding the aspect of learning engagement in young learners, a token economy plays a crucial part in motivating them to learn despite struggling in the subjects taught. The use of a token economy has been found to be one of the most successful techniques for managing behavior and enhancing students' willingness to learn. It is a critical part of teaching and learning because academic staff members are accountable for developing and delivering lessons that allow students to maximize their intrinsic potential to succeed. Teachers also believe that the success of implementing and executing a token economy in their schools improves their pupils' academic achievements [8,27,29,42,44,54,55].

Kinyanjui, A. et al. [56] conducted a study involving 4- and 5-year-old children to enhance their motor learning activities, and they concluded that reinforcement and its timing are important factors in the development of operant behavior and learning. When the use of a continuous reinforcement schedule raises the response rate, the use of a discontinuous reinforcement schedule may cause the response rate to decrease, thereby leading to the termination of such a reaction or behavior in young learners $[45,46]$.

Only a few studies have been conducted involving teachers as the main participants to assess the effectiveness of a token economy in young learners. The results have indicated that the effectiveness of classroom reinforcement tactics varies, and they should be carefully chosen. Teachers are likely to use any of the available reinforcement tactics. However, extreme caution must be exercised to avoid tactics that are considerably beyond teachers capabilities. The adoption of reinforcement mechanisms that are likely to motivate learners intrinsically should be prioritized. Extrinsic reinforcement using a token economy should lead to intrinsic reinforcement. Furthermore, individual attention should be stressed to meet the requirements and interests of students. This situation can only be accomplished if the teacher-to-student ratio is improved by lowering the current classroom population in public primary schools $[37,52,56,57]$.

Meyer, Tripp, Beckers, and Oord [34] found that high rewards and interventions can help learners with exceptional disabilities to overcome delays in conditional discrimination learning. Their findings also proved the implications of a token economy for enhancing behavioral therapy for children with special needs. These views are also supported in a few other studies in the same field using a token economy $[24,25,30]$.

- Types of token economy for education sustainability

An analysis of the literature indicated two primary categories of token types often used by researchers. The first category is social reinforcement, which has become the most popular form of incentive among pupils. The reason is that it is free of charge and does not necessitate extensive planning. Furthermore, social reinforcers can be used to communicate and praise students' work, making the relationship between students and professors or students and students considerably more personal. Applause, smiles, nods, embraces, and the signature of teachers are examples of social reinforcers. This form of token is also considered the best to offer to students as a mark of appreciation for completing tasks $[11,36]$.

Social reinforcers are also considered verbal or spoken tokens. This form of token is often used by teachers in classrooms to improve students' passion for studying, increase motivation, convey students' confidence, and enhance their attention. Furthermore, 
verbal or token reinforcement is occasionally offered to pupils, such as praising when they do something good or awarding them for their accomplishments. A simple gesture is also given as positive reinforcement. When pupils complete some of their activities properly, teachers can give positive reinforcement by smiling, giving a thumbs up, or making a favorable gesture. Although giving positive reinforcement is a simple matter, it has a significant impact on pupils' speaking and writing abilities, particularly among young learners. Various reasons are also cited for teachers to give verbal rewards in classrooms, including promoting students' excitement for learning, motivation, confidence, and attention $[37,53]$.

Students are motivated when they receive positive reinforcement in the form of vocal praise, encouragement, and recognition, and nonverbal reinforcement through a grin, pleasant facial expressions, applause, thumbs up and star gestures, or gifts, such as stationery. These positive reinforcements are given to pupils who lack learning motivation and also to children who are unmotivated in order to improve their motivation $[38,45]$.

The second most common and effective form of tokens stated in the reviewed articles is the tangible or concrete reward. The introduction of real prizes has been shown to improve students' willingness to learn, particularly in English. The discussions in the reviewed articles demonstrate this aspect. Teachers expressed a shift in the attitudes of children who were previously passive to active, students who were frequently absent to being constantly present and improvement in academic performance [11,15,57].

According to the articles, teachers and parents should use rewards sparingly when attempting to push students to read. Rewards should be ethereal rather than tangible to be effective. Teachers and parents should be aware of the attribution students make for earning rewards, as well. Although it may appear self-evident, rewards should be attributed to effort rather than luck [17].

The use of a token economy is entirely dependent on the conditions, circumstances, and learning process. Reinforcement may appear to be a straightforward method that many teachers employ, but it is frequently underutilized in terms of education sustainability. The goal of positive reinforcement has always been and will continue to be to have students actively contributing and learning in the classroom, particularly in the areas of writing and speaking. Every time the pupil applies the desired skill or behavior, the teacher or other staff member will want to provide reinforcement to keep the pupils engaged in their learning and to provide equal opportunities for them to gain quality education. The purpose of continuous reinforcement is to convince pupils that they will be rewarded if they behave appropriately [53]. Receiving rewards increased students' positive emotions, such as enjoyment, enthusiasm, relaxation, and involvement, according to the research. The data also revealed that they were pleased with the use of prizes, which aided their self-development as they were employed as external goals by a teacher. Positive reinforcement for learning behavior was achieved using rewards. The use of rewards was also successful in building more powerful activities in the classroom, which led to better-quality education [35].

In addition to a more challenging setting, learners should be given more incentives, rewards, praise, and encouragement for their responsible behavior. Motivation has a significant impact on pupils' behavior. Learners are demotivated when they believe that their creative abilities are not fully appreciated and their efforts are not adequately rewarded. Students' behavior begins to become unfavorable because of their low motivation, and they stop performing to the best of their ability [58]. However, token systems can sometimes cause students' responses to be inconsistent. A token system may be successful as a primary reinforcer, but back-up reinforcers are necessary. The efficacy of token systems may be reliant on the frequent identification of strong back-up reinforcers [59]. The use of token economy generates positive feedback in the form of improved participants' performance in a task given by a teacher [60]. A token economy is one of the ways in which structure can be introduced. It clearly explains the learning task and defines the components of the environment to be addressed by using a variety of reinforcements [61]. Due to its strong influence on motivation, it is crucial to look at their long-term effects as well as 
their acute ones [62]. When students receive rewards in the classroom, it is implied that it is beneficial to them, particularly in classroom learning activities [63]. It is worth noting that teachers also expressed general pleasure with the use of a token economy in their classroom [64], and this reaction was seen to increase pupils' overall attention to the task given [64]. Evidently, pro-social verbal and physical behaviors increased with the initiation of a token economy system [65].

\section{Conclusions}

The use of a token economy in teaching is examined through this scoping review. Past studies have shown that the use of a token economy is effective in the aspect of behavior management and learning engagement in young learners. The practice of providing tokens for learners in classrooms is commonly done in various countries. The implementation of a token economy is emphasized as an important element in 21st century classrooms. The use of a token economy is considered a crucial element in classrooms because teachers are required to have a token economy chart in their classrooms. This review assists teachers in understanding the different types of token economies that can be implemented in their classroom. Knowledge on the effective types of token economy will help teachers to avoid focusing only on a particular type of reward system for all pupils. Teachers can also decide when rewards should be given and be able to help students to enjoy their classes and be satisfied with the materials.

This study demonstrates that if a token economy is implemented properly, it can be a catalyst for changing behavior and enhancing students' academic performance. Therefore, instructors and educators should incorporate a reward or token economy system in their classrooms. The token system has been shown to be effective in terms of motivating and inspiring pupils, particularly those in primary schools. In the education context, schools could modify the token economy system as a considerably flexible and effective intervention, particularly in primary schools. Although thorough execution is required, the strategy offers considerable advantages in terms of improving education quality and providing an improved learning environment for pupils.

A token economy is an important element in teaching young learners to boost their motivation toward learning. Young learners are sensitive emotionally. Hence, educators should find a way to obtain the desired behavior from them without hurting their feelings and without using physical punishments. Accordingly, this study is essential for educators of young learners to implement the strategies presented in this study in their classrooms. The use of a token economy in the classroom also helps teachers to cater to individual learners' needs by employing a variety of token economy strategies. In their classrooms, students are recognized and given the impression of being valued for the effort they have exerted to obtain an education. This endeavor will assist students to remain motivated despite the difficulties they face in getting to school.

\section{- Limitation}

The number of papers involving the token economy in education for the chosen timeframe is limited. There are, however, many articles on the token economy found to be used in many other sectors, such as workplaces and mental health institutions. Since the focus of this study was on education settings, obtaining enough articles for the review was a challenge. In addition, most of the papers on the token economy were survey articles. It is crucial to obtain papers on experimental research or action research on the token economy to obtain a clear picture of the impact of a token economy on learners.

- Recommendations

It is perhaps pertinent to consider why a teacher chooses a particular type of token economy to employ in the classroom. Most teachers claimed that they used token economies in their classrooms. Although some of these findings provided useful information regarding the reasons that teachers used the token economy, further study into teacher attitudes and reward use is still needed. A more in-depth look at how teachers use 
one type of motivation, such as a token economy or goal setting, is another possibility for future research.

Meeting the emotional needs of all students in classrooms is a type of social fairness, which is a key notion in the sustainability movement. The educational system generally does not make the connection between teaching methods and social fairness. Previously, only students who excelled in reading, memorization, and recitation prospered in school. Those who did not frequently dropped out, restricting their career and economic opportunities. Dropping out of school is a significant social and economic issue. By implementing a token economy in classrooms, teachers will be able to address fairness in the classroom. This practice also demonstrates to students how equity and social sustainability may take several forms. If these pedagogies are used in schools, then they, similar to other educational methods, can help to promote education sustainability goals.

Author Contributions: Conceptualization, K.H.T. and M.K.; methodology, K.H.T.; validation, K.H.T.; formal analysis, M.K. and K.H.T.; investigation, M.K.; resources, K.H.T.; data curation, M.K. and K.H.T.; writing — original draft preparation, K.H.T. and M.K.; writing—review and editing, K.H.T. and I.H.A.; supervision, K.H.T.; project administration, M.K.; funding acquisition, I.H.A. All authors have read and agreed to the published version of the manuscript.

Funding: This research is supported by the Universiti Kebangsaan Malaysia Strategic Research Grant coded KRA-2018-005.

Institutional Review Board Statement: Not Applicable.

Informed Consent Statement: Not Applicable.

Data Availability Statement: Not Applicable.

Conflicts of Interest: The authors declare no conflict of interest.

\section{References}

1. Skinner, B.F. Science and Human Behavior; The Free Press: New York, NY, USA, 1953; pp. 80-313.

2. Grant, M.J.; Booth, A.A. Typology Of Reviews: An Analysis Of 14 Review Types And Associated Methodologies. Health Inf. Libr. J. 2009, 26, 91-108. [CrossRef]

3. Arksey, H.; O'Malley, L. Scoping studies: Towards a methodological framework. Int. J. Soc. Res. Methodol. 2005, 8, 19-32. [CrossRef]

4. Peters, M.D.J.; Godfrey, C.M.; Khalil, H.; McInerney, P.; Parker, D.; Soares, C.B. Guidance for conducting systematic scoping reviews. Int. J. Evid. Based Health 2015, 13, 141-146. [CrossRef]

5. Lewis, M. Pedagogical implications of the lexical approach. In Second Language Vocabulary Acquisition: A Rationale for Pedagogy; Coady, J., Huckin, T., Eds.; Cambridge University Press: Cambridge, UK, 1997; p. 255.

6. Adibsereshki, N.; Abkenar, S.J.; Ashoori, M.; Mirzamani, M. The effectiveness of using reinforcements in the classroom on the academic achievement of students with intellectual disabilities. J. Intellect. Disabil. 2015, 19, 83-93. [CrossRef]

7. Ahkam, M.; Anwar, H.; Aryanti, A. The Application of Token Economy Method to Increase the Middle School Students' Motivation in Learning Mathematics. In Proceedings of the 3rd International Conference on Education, Science, and Technology (ICEST 2019), Makassar, Indonesia, 19-20 October 2019; Atlantis Press: Paris, France, 2020; pp. 165-167. [CrossRef]

8. Aljuhaish, S.F.; Othman, J.; Senom, F. Saudi EFL Teachers' Identity Formation in Saudi Schools: A case Study. Arab. World Engl. J. 2020, 11, 431-445. [CrossRef]

9. Alqahtani, R.M. The Effects of a Token Economy System to Improve Social, Academic, and Behavior Skills with Children in KSA. Int. J. Learn. Dev. 2020, 10, 11-19. [CrossRef]

10. Arkoosh, M.; Weber, K.P.; McLaughlin, T.F. The Effects of Motivational/Reward System and a Spelling Racetrack on Spelling Performance in General Education: A Case Report. Open Educ. J. 2009, 2, 17-20. [CrossRef]

11. Aziz, N.A.A.; Yasin, M.H.M. Token Economy to Improve Concentration among Students with Learning Disabilities in Primary School. J. ICSAR 2018, 2, 32-36. [CrossRef]

12. Bakara, N.A.; Zainal, M.S. The Effects Of Using Positive Reinforcement Techniques To Reduce Disruptive Behavior Of Pupil With Adhd. In Global Conferences Series: Social Sciences, Education And Humanities (Gcssseh); Redwhite Press: Padang, Indonesia, 2020; pp. 107-114. [CrossRef]

13. Boniecki, K.A.; Moore, S. Breaking the Silence: Using a Token Economy to Reinforce Classroom Participation. Teach. Psychol. 2003, 30, 224-227. [CrossRef]

14. Boyer, S. The Effects of a Token Reward System on Reading Comprehension. J. Appl. Educ. Res. 2017, 1, 4. Available online: https:/ / scholars.fhsu.edu/jaer/vol1/iss1/4 (accessed on 10 June 2021). 
15. Cahya, T.; Kusnadi, A.N.; Anggraeni, A. The Influence Of Tangible Rewards To Student's Motivation In 4th Grade Sdn Sinargalih 1 Ciranjang Students. Proj. Prof. Engl. Educ. 2018, 1, 350-356. [CrossRef]

16. Chansaengsee, S. Behavior Modification Using The Differential Reinforcement Of Low Rates Technique And Token Economy To Improve English Handwriting Among Thai Students. Hum. Behav. Dev. Soc. 2019, 20, 41-49.

17. Chen, P.-H.; Wu, J.-R. Rewards For Reading: Their Effects On Reading Motivation. J. Instr. Pedagog. 2010, 3, 1-8.

18. Chen, P.; Kuo, R.; Chang, M.; Heh, J.-S. The effectiveness of using in-game cards as reward. Res. Pract. Technol. Enhanc. Learn. 2017, 12, 1-23. [CrossRef] [PubMed]

19. Glascott, T.; Belfiore, P.J. The Effects Of Token Reinforcement, In The Form Of A Lottery, On Noncompliance In An Urban Third Grade Classroom. Psychol. Behav. Sci. Int. J. 2019, 001-007. [CrossRef]

20. Gomez, C.; Rothermel, M.; Olsen, J.; Gautum, C. Positive Reward System Encourages Student Engagement in Anatomy Courses. Int. J. Exerc. Sci. Conf. Proc. 2019, 9, 35. Available online: https://digitalcommons.wku.edu/ijesab/vol9/iss7/35 (accessed on 10 June 2021).

21. Hahs, A.D.; Miller, S. ABA in the Special Education Classroom: Promoting; Scientific \& Academic Publishing: Rosemead, CA, USA, 2014; pp. 95-102. [CrossRef]

22. Hakulinen, L.; Auvinen, T.; Korhonen, A. The Effect of Achievement Badges on Students' Behavior: An Empirical Study in a University-Level Computer Science Course. Int. J. Emerg. Technol. Learn. 2015, 10, 18. [CrossRef]

23. Hemamalini, D.T. Effectiveness Of Token Economy In Reducing Temper Tantrums Among The Intellectually Disabled Children. Int. J. Indian Psychol. 2020, 8, 155-161. [CrossRef]

24. Higgins, J.W.; Williams, R.L.; Mclaughlin, T.F. The Effects Of A Token Economy Employing Instructional Consequences For A Third-Grade Students With Learning Dissabilities: A Data-Based Case Study. Educ. Treat. Child. 2001, 24, 99-106.

25. Hopewell, K.; McLaughlin, T.F.; Derby, K.M. The Effects of Reading Racetrack with Direct Instruction Flashcards and a Token System on Sight Word Acquisition For Two Primary Students with Severe Conduct Disorders. Electron. J. Res. Educ. Psychol. 2017, 9, 693-710. [CrossRef]

26. Ihiegbulem, O.T.; Ihiegbulem, V.N.; Igwebuike, D. Effect of Token Economy on Academic Achievement of Secondary School Students: Implications for Counselling. Mediterr. J. Soc. Sci. 2011, 2, 87. Available online: https://www.richtmann.org/journal/ index.php/mjss/article/view/10886 (accessed on 19 June 2021).

27. Indrawati, I.; Marzuki, M.; Malik, A.R. Investigating The Effect Of Reward And Punishment On The Student's Learning Achievement And Discipline. Linguist. Engl. Educ. Art (LEEA) J. 2021, 4, 337-350. [CrossRef]

28. Irianjani, N.D.; Rohmah, F.A. Applying token economy to improve attention of child with ADHD. J. Early Child. Care Educ. 2020, 3, 1-13. [CrossRef]

29. Kasyulita, E.; Armelida. An analysis of students' motivation in learning english after given rewards at the eight grade students' of smpn 3 rambah. J. Engl. Educ. 2019, 5, 23-36. [CrossRef]

30. Klimas, A.; Mclaughlin, T.F. The Effects Of A Token Economy System To Improve Social And Academic Behavior With A Rural Primary Aged Child With Dissabilities. Int. J. Spec. Educ. 2007, 22, 72-77.

31. Leblanc, G. Enhancing Intrinsic Motivation Through The Use Of A Token Economy. Essays Educ. 2004, 11, 1-20.

32. Lun, B.W.; Dhillon, S.K.; Ahmad, K. The Introduction Of A Secondary Reinforcer During Therapy Based On The Aba Model For Children With Autisme. J. Sains Kesihat. Malays. 2016, 14, 89-102. [CrossRef]

33. Metekohy, B.; Sahertian, N.L.; Ming, D. Contribution Of Token Type Cooperative Learning Models For In The Haruru Christian Middle School. Psychol. Educ. 2021, 58, 982-994. [CrossRef]

34. Meyer, H.D.; Tripp, G.; Beckers, T.; Oord, S.V. Conditional Learning Deficits In Children With Adhd Can Be Reduced Through Reward Optimization And Response-Specific Reinforcement. Res. Child Adolesc. Psychopathol. 2021, 49, 1165-1178. [CrossRef]

35. Phungphai, K.; Boonmoh, A. Students' Perception towards the Use of Rewards to Enhance Their Learning Behaviours and Self-Development. JEE (J. Engl. Educ.) 2021, 7, 39-55. [CrossRef]

36. Prawiro, I.Y.; Anggrarini, N. An Exploration Of Potential Rewards In English For Young Learner (EYL) Classroom. Wiralodra Engl. J. 2019, 3, 329-343. [CrossRef]

37. Putri, N.; Refnaldi, R. Rewards And Punishments Given By The Teacher In Teaching English As Foreign Language In Indonesian Context. J. Engl. Lang. Teach. 2020, 9, 75. [CrossRef]

38. Purba, J.M.; Putri, D.E. Effect Of Token Economy Therapy For Reducing Attachment Behavior Among Pre-School Children In Kindergarten. Elevate 2018, 1, 70-75. [CrossRef]

39. Rijal, F.S.; Dahlan, T.H. The Design of Behavior Modification Program with Token Economy in Elementary School. In Proceedings of the International Conference on Educational Psychology and Pedagogy_ “Diversity in Education" (ICEPP 2019), Bandung, Indonesia, 2 May 2019; Atlantis Press: Paris, France, 2020; pp. 106-109.

40. Saber, J.L. Dojo Tokens: The Effects Of A Token Economy On Undergraduate Student behavior And Performance. J. Adv. Mark. Educ. 2017, 25, 1-13.

41. Shakespeare, S.; Peterkin, V.M.S.; Bourne, P.A. A Token Economy: An Approach used for Behaviour Modifications among Disruptive Primary School Children. Int. J. Emerg. Ment. Health Hum. Resil. 2018, 20, 1-11. [CrossRef]

42. Sidiq, M.S.; Mulawarman, M.; Awalya, A. The Effectiveness Of Behavioral Counseling With Token Economy And Behavior Contract Techniques To Reduce Academic Procrastination. J. Bimbing. Konseling 2020, 9, 76-84. [CrossRef] 
43. Stanfield, G.M. Incentives: The Effects on Reading Attitude and Reading Behaviors of Third-Grade Students. Corinthian 2008, 9, 8. Available online: https://kb.gcsu.edu/thecorinthian/vol9/iss1/8 (accessed on 10 June 2021).

44. Stephen, V.K.; Singh, D.P. Study Of The Relationship Between Student And Teachers In Terms Of Reinforcement In Primary Schools Of The Allahabad. IOSR J. Humanit. Soc. Sci. 2017, 22, 26-33. [CrossRef]

45. Sumiati, T.; Septiani, N.; Widodo, S.A.; Caturiasari, J. Building children's learning motivation through positive reinforcement in science and math classroom. J. Phys. Conf. Ser. 2019, 1318, 012023. [CrossRef]

46. Syamsudin, M.A.; Rasyid, H. The Effects of Verbal Reward and Punishment on Gross Motor Learning Activities for Children 4-5 Years Old. In Advances in Social Science, Education and Humanities Research, Proceedings of the International Conference on Special and Inclusive Education (ICSIE 2018), Yogyakarta, Indonesia, 25-26 October 2018; Atlantis Press: Paris, France, 2019; Volume 296, pp. 387-390. [CrossRef]

47. Tiano, J.D.; Fortson, B.L.; McNeil, C.B.; Humphreys, L.A. Managing classroom behavior of Head Start children using response cost and token economy procedures. J. Early Intensiv. Behav. Interv. 2005, 2, 28-39. [CrossRef]

48. Whitney, T.; Cooper, J.T.; Lingo, A.S. Using A Token Economy Combined With A Mystery Motivator For A Student With Autism Exhibiting Challenging Behavior. Kentucky Teacher Education. J. Teach. Educ. Div. Ky. Counc. Except. Child. 2019, 5, 1-23.

49. Yaseen, M.K.; Tahar, M.M. The Use Of Economy Token To Reduce Tantrum Among Autistic Students. J. Penelit. Dan Pengemb. Pendidik. Luar Biasa 2018, 5, 20-25.

50. Zlomke, K.; Zlomke, L. Token economy plus self-monitoring to reduce disruptive classroom behaviors. Behav. Anal. Today 2003, 4, 177-182. [CrossRef]

51. Irawati, I.; Syafei, A.F. The Use Of Reward And Punishment To Increase Young Learners' Motivation In Learning English As Foreign Language Adapted To Indonesian Context. J. Engl. Lang. Teach. 2016, 5, 265-271. [CrossRef]

52. Loi, D.P.; Uyen, N.T. Motivating Efl Classroom Participation By Rewarding. J. Appl. Linguist. Lang. Res. 2016, 3, 177-189.

53. Sari, N.W.I.; Paradina, N.L.P.T. The Use of Reinforcement in Writing and Speaking Skill for Adult Learners in Mahasaraswati University. In Proceedings of the 5th Asia Pasific Education Conference (AECON 2018), Purwokerto, Indonesia, 13-14 October 2018; Atlantis Press: Paris, France, 2018; pp. 111-119.

54. Jabeen, L.; Iqbal, N.; Haider, N.; Iqbal, S. Cross Correlation Analysis of Reward \& Punishment on Students Learning Behavior. Int. Lett. Soc. Humanist. Sci. 2015, 59, 61-64. [CrossRef]

55. Khaliq, D.A.; Douna, M.S.; Ahsan, M. Role Of Reinforcement Or Punishment In Learning English Language: A Study At Secondary Level In Southern Punjab Pakistan. Int. J. Bus. Soc. Sci. 2016, 7, 137-146.

56. Kinyanjui, M.W.; Aloka, P.J.; Mutisya, S.K.; Ndeke, F.N.; Nyang'Ara, N.M. Classroom Reinforcement Schedules and Their Effectiveness in Selected Kenyan Primary Schools. J. Educ. Soc. Res. 2015, 5, 41-52. [CrossRef]

57. Sak, A.P.; Sak, A.P.; Çiçek, L.B. The Persistence Of Reward And Punishment In Preschool Classrooms. J. Educ. Instr. Stud. World 2016, 6, 55-63.

58. Ali, Z.; Tatlah, I.A.; Saeed, M. Motivation And Student's Behavior: A Tertiary Level Study. Int. J. Psychol. Couns. 2011, 3, 29-33.

59. Fiske, K.E.; Isenhower, R.W.; Bamond, M.J.; Delmolino, L.; Sloman, K.N.; LaRue, R.H. Assessing the value of token reinforcement for individuals with autism. J. Appl. Behav. Anal. 2015, 48, 448-453. [CrossRef] [PubMed]

60. Steel, A.; Silson, E.H.; Stagg, C.J.; Baker, C. The impact of reward and punishment on skill learning depends on task demands. Sci. Rep. 2016, 6, 36056. [CrossRef] [PubMed]

61. Varghese, S.C.; Valsaraj, B.P.; Shalini. Effectiveness Of Token Economy On Temper Tantrum Among Intellectually. Int. J. Health Sci. Res. 2015, 6, 264-269. Available online: https://www.ijhsr.org/IJHSR_Vol.6_Issue.1_Jan2016/39.pdf (accessed on 10 June 2021).

62. Visaria, S.; Dehejia, R.; Chao, M.M.; Mukhopadhyay, A. Unintended consequences of rewards for student attendance: Results from a field experiment in Indian classrooms. Econ. Educ. Rev. 2016, 54, 173-184. [CrossRef]

63. Widya, D.; Wantina, Y.A.S. The Implementation Of Reward And Punishment Towards Student Perception In English Learning At Ikip Siliwangi. Prof. J. Engl. Educ. 2019, 2, 776-782. [CrossRef]

64. Williamson, R.L.; Mcfadzen, C. Evaluating The Impact Of Token Economy Methods On Student On-Task Behavior Within An Inclusive Canadian Classroom. Int. J. Technol. Incl. Educ. 2020, 9, 1531-1541. Available online: https://infonomics-society.org/wpcontent/uploads/Evaluating-the-Impact-of-Token-Economy-Methods-on-Student.pdf (accessed on 10 June 2021). [CrossRef]

65. Wolfe, B.D.; Dattilo, J.; Gast, D.L. Effects Of A Token Economy System Within The Context Of Cooperative Games On Social Behaviors Of Adolescents With Emotional And Behavioral Disorders. Ther. Recreat. J. 2003, 37, 124-141. 